PF 2020 (75/1): 293-312

https://doi.org/10.32798/pf.662

\author{
VERONIKA KOLÁŘOVÁ \\ Matematicko-fyzikální fakulta \\ Univerzita Karlova \\ Ústav formální a aplikované lingvistiky, Praha \\ e-mail: kolarova@ufal.mff.cuni.cz
}

ORCID 0000-0001-5184-579X

\title{
VZTAH AFIRMATIVNÍ A NEGOVANÉ FORMY ADJEKTIV A SUBSTANTIV Z HLEDISKA JEJICH VALENCE $^{1}$
}

\section{RELATION OF AFFIRMATIVE AND NEGATIVE FORMS OF ADJECTIVES AND NOUNS FROM THE POINT OF VIEW OF THEIR VALENCY}

\begin{abstract}
When treating valency of adjectives and nouns in a valency lexicon, it is necessary to decide whether their affirmative and negative forms can be captured in one entry, e.g. (ne)závislý '(in)dependent' and (ne)závislost '(in)dependence'. There are two cases that would justify separate entries in the lexicon: first, a difference in meaning between an affirmative form and the corresponding negative form, e.g. volnost 'freedom' vs. nevolnost 'indisposition'; second, a difference in their valency, cf. dependent on and independent of. With the focus on valency complementations expressed by a prepositional group, we show that the valency of negative forms of Czech adjectives and nouns in corpus data is, with few exceptions, the same as valency of the corresponding affirmative forms, e.g. (ne)spokojenýs ším '(un)satisfied with sth', (ne)spokojenost s čim '(dis)satisfaction with sth. However, it often differs in frequency. When capturing valency of affirmative and negative forms in one entry in a lexicon, it is important to treat not only the most common cases but also less frequent negative forms and their valency (e.g. nevděčný za něco 'ungrateful for sth'), as well as the opposite cases in which the frequency of a negative form and its valency considerably outnumbers the frequency of the corresponding affirmative form (e.g. nepostradatelný pro někoho 'indispensable to sb').
\end{abstract}

1 Tento př́spěvek vznikl za podpory grantového projektu Grantové agentury ČR s názvem „Valence neslovesných predikátư“ (GA19-16633S). Tato studie využívá jazykové zdroje a nástroje vyvinuté, uchovávané a distribuované v rámci projektu Ministerstva školství, mládeže a tělovýchovy ČR „Digitální výzkumná infrastruktura pro jazykové technologie, umění a humanitní vědy“ (LM2018101). 
KEYWORDS: valency lexicon, negation, adjectives, nouns

KLÍČOVÁ SLOVA: valenční slovník, negace, adjektiva, substantiva

SŁOWA KLUCZOWE: słownik walencyjny, negacja, przymiotniki, rzeczowniki

\section{1. Úvod}

Při zpracování valence adjektiv a deadjektivních a deverbativních substantiv ve valenčním slovníku NomVallex ${ }^{2}$ je třeba v jednom z prvních kroků rozhodnout, zda je možné afirmativní a negované formy daných slov zpracovat v jednom hesle, resp. lexému, např. (ne)spokojený, (ne)spokojenost, (ne)zajímání se, (ne)zájem, nebo zda jsou důvody pro vydělení dvou samostatných hesel, např. volnost ('svoboda') a nevolnost ('neprŕijemný tělesný stav'). V této práci zkoumáme předložkovou valenci negovaných forem vybraných adjektiv a substantiv; nejprve věnujeme pozornost možnostem tvoření negovaných forem deverbativních substantiv (srov. nezajímání se o něco - nezájem o něco, ale nevyzvání k čemu vs. *nevýzva $k$ čemu; odd. 4.1) a poté srovnáváme předložkovou valenci u afirmativních a negovaných forem vybraných adjektiv a deadjektivních substantiv (např. (ne)závislý na čem, (ne)závislost na čem, ale nevěrný komu s kým vs. věrný komu *s kým; odd. 4.2). Naším cílem je zjistit, zda předložková valence českých negovaných a afirmativních forem není natolik odlišná, že by bylo třeba je ve slovníku zpracovat odděleně (jako např́lklad anglické dependent on a independent of). Zároveň identifikujeme problémy, které by při zachycení obou forem adjektiv nebo substantiv v jednom slovníkovém hesle mohly nastat (odd. 4.2 a 5).

Práce založené na korpusových datech, které si kladou podobné otázky z hlediska zachycení afirmativních a negovaných forem ve výkladových slovnících (Kováŕíková 2011; Kováříková et al. 2012), ukazují, že zatímco téměř 99 \% z vybraných slovesných lemmat se vyskytuje jak v afirmativní, tak v negované podobě, $\mathrm{u}$ adjektiv je to jen $48 \%$ a u substantiv dokonce pouze $12 \%$. U adjektiv pak platí, že čím vyšší je jejich frekvence, tím vyšší je jejich pokrytí negovanými formami. U vysoce frekventovaných adjektiv by tedy podle těchto prací bylo možné uvažovat o zachycení jejich afirmativní a negované formy v jednom hesle, u méně frekventovaných adjektiv a u substantiv však nikoli. Zohledníme-li ovšem slovotvorné hledisko, je zřejmé, že možnost tvoření negovaných forem adjektiv a substantiv závisí i na jejich typu a významu (odd. 2 a 4.1).

2 https://ufal.mff.cuni.cz/nomvallex 
$S$ pojmem valence pracujeme v teoretickém rámci Funkčního generativního popisu, který u sloves, substantiv i adjektiv rozlišuje aktanty, tj. Aktor (ACT), Patiens (PAT), Adresát (ADDR), Efekt (EFF) a Původ (ORIG), např. néčí.ACT věrnost někomu.PAT ${ }^{3}$, a volná doplnění, např. Účel (AIM), určený k čemu.AIM, blíže viz Panevová (1980; 1998; 2002; 2006). Opíráme se o korpusový materiál řady SYN Českého národního korpusu (ČNK; Křen et al. 2019), odd. 3. ${ }^{4}$

\section{Negované formy sloves, adjektiv a substantiv - přehled}

Tvoření negovaných forem sloves a některých dalších slovních druhů pomocí prefixu ne- bývá řazeno k modifikaci prefixací (Rusínová 2016; Sokolová et al. 1999). U adjektiv a substantiv vzniká podle Šimandla et al. (2016) teoretická otázka, zda se tvoří negací jejich kladné podoby (např. nezávislý $\leftarrow$ závislý, nezávislost $\leftarrow$ závislost), nebo sufixací z již negovaných základových slov (nezáviset $\rightarrow$ nezávis-l-ý $\rightarrow$ nezávisl-ost); rozhodnutí ve prospěch jedné z těchto možností je pak nezbytnou součástí grafického znázornění derivačních vztahů v elektronických derivačních databázích, pro češtinu např. v lexikální síti DeriNet (Ševčíková et al. 2016, s. 73).

U sloves se předpokládá, že negovat lze univerzálně všechna slovesa, nebo alespoň všechny jejich tvary (Rusínová, Osolsobě 2016; Pavlovič 2015, s. 1369; Štícha et al. 2013), což se projevuje i ve skutečnosti, že slovníky zpravidla uvádějí pouze jejich afirmativní formy. $U$ adjektiv a substantiv je však situace složitější. Vedle samotné potenciality negace afirmativních tvarů je navíc třeba věnovat pozornost takovým adjektivům a substantivům začínajícím řetězcem ne-, k nimž afirmativní forma v současném jazyce neexistuje (tzv. negativa tantum, např. nehorázný), a dále negovaným formám, které se v jednom ze svých významů lexikalizovaly a v tomto jednotlivém významu dvojici s afirmativní formou netvoří, srov. (ne)možný ${ }_{1}$ - (ne) možnost $_{1}$ (tj. (ne)existence možnosti, viz (1)) a nemožný ${ }_{2}$ (neschopný) - nemožnost ${ }_{2}$ (neschopnost, viz (2)). V neposlední řadě je třeba vydělit př́ípady, kdy negativní i afirmativní forma sice existují, ale mají odlišný význam (srov. mocný vs. nemocný, smyslný vs. nesmyslný, volnost vs. nevolnost). Stranou našeho zájmu zůstávají okazionální užití negovaných forem substantiv ve vylučovacích konstrukcích typu „Zákaz - nezákaz, nalej!“(Pavlovič 2015), viz např. (3).

(1) Jde o nemožnost ${ }_{1}$ použití výtahu, který je mimo provoz.

(2) Všem je to trapné, já se stydím, ale on dál přesvědčuje všechny o mé nemožnosti.

(3) Žárlivost nežárlivost, věc má širší pozadí, abych tak řekl.

3 U kvantitativních substantiv připadá v úvahu také aktant Materiál (MAT), např. poloprázdné balení lékủ.MAT.

4 Všechny př́iklady uvedené v této studii pocházejí z korpusu SYNv8. 
Adjektiva jsou podle odborné literatury (Pavlovič 2015, s. 1369; Šimandl et al. 2016) dalším slovním druhem s vysokým počtem negovaných forem; lze mezi nimi rozlišovat zejména (a) adjektiva kvalitativně klasifikační, např. neznámý, nebezpečný, neštastný, nepřátelský, neviditelný, nezdravý, nevšední, a (b) adjektiva vyjadřující menší míru příznaku, např. nevelký, nevysoký, necelý. Detailnější dělení typů negovaných adjektiv podává Rechzieglová (1995), která kromě výše uvedených druhů vyděluje např. adjektiva kontextová, jejichž smysluplnost je úzce vázána na určitý specifický kontext (např. nekanalizační, nemlékárenský), a adjektiva, která jsou sice slovotvorně negativní, ale sémanticky pozitivní (např. neproblematický, nebojácný a nezávadný). Z deverbativních adjektiv se v negované podobě velmi často vyskytují adjektiva zakončená na -telný (např. neovladatelný; Karlík, Ziková 2016). Podílu negace na realizacích departicipiálních forem na -cí se věnovala Richterová (2017), možnost negace je také diskutována jako indikátor při rozlišení stavových a dějových participií (Caha 2016; srov. Ten voják

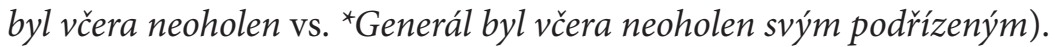

Pokud jde o možnost negace substantiv, záleží na jejich typu. Podle Štíchy et al. (2013) je tvoření negovaných forem substantiv omezené, přičemž se týká převážně substantiv abstraktních (např. nepravda, neochota, nezájem). Z abstraktních deverbativních substantiv negaci systematicky umožňují pouze jména zakončená sufixy -ní/-tí (tzv. kmenové deriváty; napr. neuklidit koupelnu - neuklizení koupelny), na rozdíl od substantiv odvozených od sloves dalšími sufixy, včetně sufixu nulového (tzv. kořenové deriváty; srov. * neúklid koupelny; Dvořák 2016a; Dvořák 2016b; Karlík 2019). Nejmenší pozornost byla dosud věnována negaci u deadjektivních substantiv (Veselá 2004).

Dosavadní poznatky více méně korespondují s lemmatizací sloves, adjektiv a substantiv v českých korpusech ${ }^{5}$. V ČNK jsou negativní tvary sloves a většiny adjektiv lemmatizovány jako afirmativní lemma, např. adjektivum nezávislý je lemmatizováno jako závislý, přičemž př́padná negace je zohledněna na 11. pozici morfologické značky (A pro afirmativ, N pro negaci; Osolsobě 2014). Substantiva pak mají zvláštní lemma pro negované formy a zvláštní lemma pro afirmativní formy (např. dvě separátní lemmata závislost a nezávislost). V Pražském závislostním korpusu (PDT) ${ }^{6}$ mají kromě sloves společné lemma také afirmativní a negované formy některých adjektiv a substantiv (konkrétně substantiva na -ní/-tí a substantiva na -ost), přičemž negace je zohledněna v gramatému negace (Veselá 2004; Mikulová et al. 2005).

Valenční slovníky zachycující valenci českých adjektiv a substantiv se k problematice negovaných forem stavějí různým způsobem. PDT-Vallex ${ }^{7}$ (Hajič

K anotaci negace ve vybraných zahraničních korpusech viz Jimenez-Zafra et al. (2020).

LDC Catalog No.:LDC2006T01, http://hdl.handle.net/11858/00-097C-0000-0001-B098-5

http://hdl.handle.net/11858/00-097C-0000-0023-4338-F 
et al. 2003), propojený s daty Pražského závislostního korpusu, zachycuje afirmativní a negované formy některých adjektiv a substantiv v jednom hesle, např. substantivum nezávislost je zpracováno pod heslem závislost, adjektivum nepř́istupný pod heslem prístupný, ale např. i adjektivum nezbytný je zpracováno pod heslem pro afirmativní formu, tedy zbytný. Slovník slovesných, substantivních a adjektivních vazeb a spojení (Svozilová et al. 2005) uvádí afirmativní a negované formy adjektiv i substantiv jako samostatná hesla, např. dostupný a nedostupný, jistota a nejistota, souhlas a nesouhlas. Valenční slovník NomVallex I. (Kolářová et al. 2020), zachycující valenci vybraných deverbativních substantiv, negované formy a jejich valenci nezohledňuje.

$\mathrm{Z}$ výše uvedeného přehledu vyplývá, že negované formy je možné očekávat nejen u velké části adjektiv, ale ve větší míře také u substantiv zakončených sufixy -níl-tí a -ost. Zatímco u substantiv na -ní/-tí se - podobně jako u sloves - předpokládá paradigmatické tvoření negovaných forem, $\mathrm{u}$ adjektiv a u substantiv na -ost je $\mathrm{v}$ mnoha př́padech užívání konkrétních negovaných forem z pohledu rodilého mluvčího nejisté a pouze pohled do korpusu ukáže, zda (a s jakou frekvencí) se užívají, viz např. dle nás příznakové a co do frekvence také zcela ojedinělé doklady adjektiv nehrdý, nenadšený a nenutný $\mathrm{v}(4)-(6)$ a substantiv nehrdost, nenadšenost a nenutnost $\mathrm{v}(7)-(9)$.

(4) V tom nehrdém zástupu $\mathrm{v}$ čele $\mathrm{s}$ Řeky dnes pochodují Portugalci, Irové a Španělé.

(5) Z Lary nemůže být člověk nenadšený.

(6) To je podle mého názoru naprosto nenutné a zbytečné vyhrocování situace.

(7) A do toho ještě česká vlastnost - neněmeckost -, tedy nedůkladnost, nesystémovost, neloajálnost a nehrdost na práci.

(8) Moje minulá nenadšenost ze snídaně byla naštěstí správně pochopena.

(9) Nenutnost podbízet se permanentně voličům je to, proč některé vlády nacházejí odvahu k nepopulárním krokům.

\section{Afirmativní a negované formy následované předložkou - korpusový materiál}

Samotný výskyt negovaných forem (zkráceně $\mathrm{N}$-forem) adjektiva nebo substantiva není zárukou, že se dané slovo v negované formě užívá také se stejnou valencí jako jeho afirmativní forma (A-forma). Valenční chování negovaných forem adjektiv a substantiv je tedy třeba oveřit $\mathrm{v}$ korpusových datech. $\mathrm{V}$ této práci se soustředíme na předložkovou valenci, přičemž v korpusových vyhledávkách se omezujeme na př́pady, kdy předložka bezprostředně následuje za zkoumaným 
adjektivem nebo substantivem ${ }^{8}$. Naším cílem je zjistit, která adjektiva a substantiva se vyskytují se stejnou předložkou jak v A-formě, tak v N-formě, a naopak která adjektiva nebo substantiva se $\mathrm{s}$ určitou předložkou vyskytují jen $\mathrm{v}$ jedné z nich; zatímco první prrípad svědčí o stejné valenci, druhý prŕpad by naznačoval, že se valence afirmativní a negované formy v určitých rysech liší (odd. 4).

Vzhledem $\mathrm{k}$ dosud známým možnostem tvoření negovaných forem u deverbativních substantiv (odd. 2) jsme se rozhodli v korpusových vyhledávkách zaměřených na substantiva (níže body (iii)-(v)) vyloučit kmenové deriváty, tj. substantiva na -ní/-tí (např. (ne)souhlasení s), a cíleně nevyhledávat ani afirmativní formy kořenových derivátů (např. souhlas s, zájem o). Vzorek negovaných forem substantiv (vyhledávka (v)) však - vedle deadjektivních a jiných substantiv - obsahuje i N-formy některých deverbativních kořenových derivátů. Abychom získali vzorek nejtypičtějších českých deadjektivních substantiv následovaných předložkou, omezili jsme vyhledávky afirmativních forem substantiv na jména zakončená řetězci -ost nebo -ota (níže body (iii) a (iv)).

V korpusu SYNv8 jsme tedy provedli celkem dvě vyhledávky adjektiv (i)-(ii) a tři vyhledávky substantiv (iii)-(v) následovaných předložkou; ve všech vyhledávkách jsme získali seznam více než 10000 dvojic adjektiva nebo substantiva s předložkou, kromě vyhledávky (iv), kde šlo o 3279 dvojic. U všech vyhledávek jsme provedli frekvenční distribuci, přičemž u vyhledávek (i), (ii) a (iv) jsme se zaměřili na prvních 100 nejfrekventovanějších dvojic adjektiva nebo substantiva s předložkou, u vyhledávek (iii) a (v) pak na prvních 300 dvojic.

Přehled vyhledávek:

(i) afirmativní forma libovolného adjektiva následovaná libovolnou předložkou;

(ii) negovaná forma libovolného adjektiva následovaná libovolnou předložkou;

(iii) substantivum zakončené řetězcem -ost následované libovolnou předložkou;

(iv) substantivum zakončené řetězcem -ota následované libovolnou předložkou;

(v) substantivum začínající řetězcem ne-, ale neobsahující řetězec -ní nebo - tí, následované libovolnou předložkou.

\subsection{Vzorky adjektiv}

Ve vyhledávkách afirmativních a negovaných forem adjektiv následovaných předložkou (výše vyhledávky (i) a (ii)) jsme identifikovali následující skupiny:

Zanedbáváme tedy př́pady, kdy se valence realizuje nalevo od zkoumaného adjektiva, napr. na něčem (ne)závislý, stejně jako případy, kdy mezi substantivem a předložkovým vyjádřením PAT nebo ADDR stojí jiné valenční doplnění, např. genitivní vyjádření Aktora, např. (ne) závislost této zemè.ACT na dodávkách.PAT plynu z Ruska. 
(a) vysoce frekventovaná adjektiva, která se v obou seznamech v A-formě nebo v N-formě vyskytla v první stovce nejfrekventovanějších dvojic adjektiva s předložkou, např. (ne)náročný na, (ne)vhodný $k$, (ne)úspěšný v, (ne)možnýv, (ne)spojený s, (ne) typický pro, (ne)uvedený v, nebo dokonce v první dvacítce, konkrétně (ne)závislý na, (ne)spokojenýs, (ne)vhodný pro, (ne)související s, (ne)srovnatelnýs;

(b) adjektiva, která se v obou celkových seznamech vyskytla jak v A-formě, tak v Nformě, ale jedna $\mathrm{z}$ těchto forem je preferovaná, zatímco druhá je sice možná, ale výrazně méně frekventovaná, např. preferovaná A-forma u adjektiv vděčný $z a$, zvyklý na, a naopak preferovaná $\mathrm{N}$-forma u adjektiva nevěrnýs;

(c) adjektiva, jejichž A-forma nebo $\mathrm{N}$-forma se sice vyskytuje v první stovce nejfrekventovanějších dvojic adjektiva s předložkou, ale opačná forma se v celkovém seznamu bud' vůbec nevyskytuje, nebo jen se zcela minimální frekvencí, např. vysoce frekventovaná adjektiva $\mathrm{v}$ A-formě označující výběr z nějaké množiny další $z$ / dobrý (nejlepší) z / jediný z / poslední $z$ apod., dále např. adjektiva složený $z$, společnýs, zvědavý na, bohatý na a hrdý na, př́ípadně naopak N-forma s minimálním výskytem afirmativního protějšku nepostradatelný pro.

\subsection{Vzorky substantiv}

S ohledem na obecný předpoklad, že negované formy se tvoří převážně od abstraktních substantiv (odd. 2), omezujeme se v níže uvedených vzorcích substantiv pouze na abstrakta, zatímco konkréta (napr. nemovitost) necháváme stranou:

(a) A-formy deadjektivních substantiv zakončených na -ost (vycházející z výše uvedené vyhledávky (iii)): Zaměřujeme se na substantiva, $\mathrm{k}$ nimž je běžně doložená i N-forma, s možností rozvití stejnou předložkovou skupinou, např. $z k u s ̌ e-$ nost s / v, závislost na, odpovědnost za, činnost $v$ / na, zodpovědnost za, možnost $v /$ pro, spokojenost s, pozornost na / $k$, znalost o, př́tomnost na, zpi̊sobilost $k$, spravedlnost $v$, trpělivost $s$, úspěšnost $v$, informovanost $o$, citlivost na, presnost $v$, pripravenost na, náročnost na, schopnost na, opatrnost při. Menší pozornost věnujeme substantivům, $\mathrm{k}$ nimž $\mathrm{N}$-forma sice existuje, ale její výskyty jsou spíše okazionální, např. (ne)souvislost, (ne)společnost, (ne)př́ležitost, (ne)návaznost, (ne)podobnost, (ne)pochybnost, (ne)součinnost.

(b) A-formy deadjektivních substantiv zakončených na -ota (vycházející z výše uvedené vyhledávky (iv)): Zaměřujeme se na několik substantiv, $\mathrm{k}$ nimž je běžně doložená i $\mathrm{N}$-forma $\mathrm{s}$ možností rozvití stejnou předložkovou skupinou, např. (ne)jistota $v$, (ne)ochota $k$, (ne)jednota $v$, a naopak stranou necháváme substantiva, která se v $\mathrm{N}$-formě běžně neužívají, např. hodnota, teplota, samota.

(c) N-formy deadjektivních substantiv, vycházející z výše uvedené vyhledávky (v); uvádíme u nich nejvýše první čtyři nejfrekventovanější předložky: nezaměstnanost $v /$ na / o / z, nespokojenost s / v, nezávislost na, nesrovnalost $v /$ při / $s$, nepresnost $v /$ na, nejistota $v$ / ohledně / na / z, nerovnost $v /$ na / mezi, nejasnost 
$v$ / ohledně, nečistota $z$ / $v$ / na / do, neporazitelnost $v$ / na, nedbalost při / s, nemocnost $v / z$ / na, nehodovost na / v, nevraživost mezi / vůči, neprítomnost $v$ / na, nestabilita $v$, nedi̊slednost $v$, neschopnost $v$, nepř́ijemnost $s / v$, neochota $k$, nevěra $s / v$, nemohoucnost $v$, nelibost nad, neopatrnost prí, nepozornost $v$, nezbytnost pro, nečinnost $v$. U některých substantiv $\mathrm{z}$ dané vyhledávky netvoří řetězec nev současném jazyce záporku, ale součást kořene, např. nehodovost, nemocnost, nevraživost, u některých jiných se sice jedná o záporku, ale v současném jazyce $\mathrm{k}$ nim afirmativní forma neexistuje, např. nesrovnalost vs. ${ }^{*}$ srovnalost, případně existuje, ale je výrazně méně užívaná než $\mathrm{N}$-forma, např. nemohoucnost vs. mohoucnost, nezbytnost vs. zbytnost.

(d) N-formy deverbativních kořenových derivátů, vycházející z výše uvedené vyhledávky (v): nesouhlas $s$, neúspěch $v$, nezájem o, neshoda $s$, nedůvěra $k / v$, neúcta $k$ a neúčast na. U některých substantiv $\mathrm{z}$ vyhledávky tvoří řetězec ne$\mathrm{v}$ současném jazyce součást kořene, např. nenávist.

\section{Předložková valence afirmativních a negovaných forem}

Vztahu afirmativních a negovaných forem z hlediska jejich valence zatím nebyla věnována dostatečná pozornost; např. práce pojednávající o valenci českých adjektiv (např. Prouzová 1983; Kopřivová 2006; Panevová 2006; Skwarska 2018) a substantiv (např. Panevová 2002; Čermáková 2009; Kolářová et al. 2020) se o problematice valence negovaných forem nezmiňují. Vlivu negativních prefixů na argumentovou strukturu slovních základů ve španělštině a okrajově také v angličtině se věnuje např. Curiel (2015, s. 1357-1358); konstatuje, že negativní prefixy zpravidla argumentovou strukturu slovních základi̊ neovlivňují (napr. That's not / (un-)clear to me), nicméně existují případy, kdy slovo s negativní předponou získá nový význam a argumentová struktura slova s tímto novým významem se od původního slova liší, srov. španělská slovesa aparecer 'objevit se' (někde) a desaparecer 'zmizet' (někde, ale i odkud). Nezmiňuje však případy, kdy negativní předpona význam slova nemění, pouze neguje, a přesto má dané slovo odlišnou valenci, jako je tomu např. u dvojice anglických adjektiv dependent on vs. independent of, případně anglických substantiv dependence on vs. independence from / of.

V této studii zkoumáme valenci negovaných (nikoli negativní předponou změněných) významů českých adjektiv a substantiv, tedy takových $\mathrm{N}$-forem, u kterých by bylo možné uvažovat o zachycení ve slovníku v rámci jednoho hesla spolu s prŕślušnou A-formou (např. (ne)závislost na dodávkách plynu z Ruska). Zaměřujeme se na předložkové vyjádření jejich aktantů, zejména Patientu, např. nezodpovědnost za své jednání.PAT, případně Adresátu, např. nezodpovědnost ke svému dítěti.ADDR (ke způsobu získání jazykového materiálu viz odd. 3). Zatímco u adjektiv nezohledňujeme, zda jsou odvozená, nap̌r. (ne)závislý na, nebo 
neodvozená, např̀. (ne)jistý $v$, u substantiv se věnujeme zvlášt deverbativním substantivům (odd. 4.1) a zvlášt deadjektivním substantivům, která zkoumáme společně s jejich základovými adjektivy (odd. 4.2).

\subsection{Deverbativní substantiva}

Jak již zaznělo výše (odd. 2; Dvořák 2016a; Karlík 2019), u kmenových derivátů se předpokládá paradigmatické tvoření negovaných forem. Je však třeba upřesnit, že negaci systematicky umožňují pouze kmenové deriváty označující událost (např. nebalení dárků se ukázalo jako špatný nápad, nevyznamenání bratrů Mašinů). V těchto prrípadech si negované formy kromě jiných verbálních morfosyntaktických vlastností, napr. spojitelnosti s reflexivem se/si (nezajímání se o něco, neuvědomění si něčeho), zachovávají i stejnou valenci jako afirmativní formy, viz např. genitivní vyjádření Adresátu a předložkové vyjádření Patientu v (10) nebo genitivní vyjádření Patientu a instrumentálové vyjádření Aktora v (11); k morfosyntaktickým vlastnostem kmenových derivátů a k dalším možnostem morfematického vyjádření jejich valenčních doplnění viz např. Kolářová et al. (2020). K negaci však nedochází u lexikalizovaných významů kmenových derivátů, označujících např. substanci (např. uniforma zdobená *nevyznamenáními) nebo množství (tj. u kvantitativních substantiv, nap̌r. poloprázdné *nebalení léků). U kmenových derivátů označujících abstraktní výsledek děje je situace složitější; některé negaci spíše neumožňují (např. ${ }^{*}$ nevyznamenání bratrům Mašínưm, * necitění pro estetiku, národní *neuvědomèní), jiné ano (napr. nepochopení pro tyto otázky), přičemž do značné míry záleží na jazykové kreativitě mluvčích, srov. (12). V některých př́padech dochází naopak k lexikalizaci negovaných forem, napřr. mnohá nedorozumění s lidmi.

(10) nevyzvání uchazečů.ADDR k doplnění.PAT podkladů sloužících k prokázání kvalifikace

(11) dvě události související s kontroverzí okolo údajně záměrného nevyznamenání oběti.PAT holocaustu Jiř́iho Bradyho prezidentem.ACT Zemanem

(12) Řekněme, že projevuje určité nenadšení z některé mé činnosti.PAT.

Negované formy kořenových derivátů, které se vyskytly v našem korpusovém vzorku ((d) v odd. 3.2), se zpravidla mohou vyskytnout se stejnou valencí jako jejich afirmativní formy, např. (ne)zájem o něco, (ne)souhlas s čím, (ne)důvěra $v$ něco, (ne)úspěch $v$ něčem, v některých prrípadech však s odlišným významem, srov. shoda s čím vs. neshody s kým. Ve srovnání s pokrytím $\mathrm{N}$-forem u kmenových derivátů jsou ovšem kořenové deriváty umožňující negaci vzácné; například z počtu 89 lemmat kořenových derivátů obsažených ve slovníku NomVallex I. (Kolářová et al. 2020) umožňuje negaci ani ne desetina substantiv, konkrétně 
(ne)zájem, (ne)dohoda, (ne)komunikace, a dále výrazně méně doložené (ne)obliba, (ne)respekt, (ne)radost a (ne)lítost, jejichž valenci je vzhledem $\mathrm{k}$ jejich menší frekvenci opět třeba ověřit v korpusu, viz (13) a (14).

(13) Výzkumy CERGE však na druhou stranu ukazují extrémní neoblibu českých žáků.ACT v učení.PAT se matematice.

(14) Nejvíc mi vadí ten nerespekt k naší profesi.PAT.

\subsection{Adjektiva a deadjektivní substantiva}

Z dvojic adjektiv a deadjektivních substantiv s předložkou získaných na základě vyhledávek uvedených v odd. 3 jsme $k$ další analýze vybrali ty, u nichž daná předložka může být součástí takové předložkové skupiny, která představuje valenční doplnění daného adjektiva nebo substantiva, tj. např. ze vzorku (c) v odd. 3.2 byla mezi jinými vybrána dvojice nespokojenost s (č́m), nikoli nezaměstnanost $z$ (čeho). U vybraných adjektiv a od nich odvozených substantiv jsme pak v korpusu SYNv8 vyhledali frekvence jejich A-forem a $\mathrm{N}$-forem následovaných určitou předložkou, přičemž oproti vyhledávkám popsaným v odd. 3 jsme se již u předložek, které se pojí s různými pády (např. na+Ak vs. na+Lok), zaměřili jen na požadovanou předložkovou skupinu'. Vyhledané frekvence shrnujeme v tabulce 1 , kde kromě absolutních frekvencí uvádíme také poměr počtu $\mathrm{N}$-forem ku počtu A-forem (pro lepší přehlednost násobený stem). Rozdíly v poměru počtu $\mathrm{N}$-forem a A-forem jsou určitým vodítkem při srovnání jejich předložkové valence: je-li užití $\mathrm{N}$-formy s danou předložkou běžné a hojně doložené (např. neprípravený na, nezávislý na, neprátelský $k$, nezpiosobilý $k$ ), pohybuje se pomèr počtu jejích výskytů ku počtu výskytů A-formy v rozmezí 0,015-0,35 (v tabulce 1,5-35). Oproti tomu extrémní hodnoty poměru stejně jako nízké absolutní frekvence vždy vybízejí k dalšímu prozkoumání; doklady s poměrem počtu $\mathrm{N}$-formy ku A-formě menším než 0,01 (v tabulce poměr 1) nebo s absolutní frekvencí nižší než 100 je třeba ověřit v korpusu (nap̌r. nevděčný $z a$, nezodpovědný za, nezvědavost na; odd. 4.2.1), naopak poměr kolem 1 ( $\mathrm{v}$ tabulce 100) nebo dokonce

\footnotetext{
Např. u adjektiva nezvyklývyhledáváme doklady s předložkou na následovanou substantivem $\mathrm{v}$ akuzativu (při použití dotazu [lemma="nezvyklý"] [lemma="na"] [!(tag=" $[\mathrm{Z}|\mathrm{R}| \mathrm{V} \mid \mathrm{J}]$. .")] $\{0,2\}$ [tag="N...4. *”] je jedním z dokladů např. člověk nezvyklý na alkohol.PAT), nikoli však s předložkou na následovanou substantivem v lokálu, vyjadřujícím místní určení, nap̌r. jev nezvyklý na londýnských ulicích.LOC. U hojně doložených dvojic adjektiva nebo substantiva s předložkou ovšem neprovádíme manuální kontrolu všech nalezených dokladů, zanedbáváme tedy př́pady, které neodpovídají intenci našeho dotazu, např. na poloostrově je poměrně teplo, nezvyklé na tuto roční dobu. REG. Doklady s absolutní frekvencí nižší než 100 však zkontrolovány byly, aby byly identifikovány takové dvojice adjektiva nebo substantiva s předložkou, které ve skutečnosti nejsou doklady na očekávanou valenci (např. mezi doklady dvojice věrnýs není ani jeden doklad na valenci adjektiva věrný).
} 
vyšší naznačuje odlišnosti ve valenci (např. nevěrný $s$, nejistota $z$; odd. 4.2.2). Vždy je však třeba přihližžet $\mathrm{k}$ individuálním vlastnostem jednotlivých adjektiv nebo substantiv; např. adjektivum (ne)spokojený a od něj odvozené substantivum (ne)spokojenost se $\mathrm{v}$ afirmativní i negované formě zcela běžně vyskytuje s Patientem vyjádřeným předložkovou skupinou s+Ins, adjektivum rozvité tímto doplněním však preferuje A-formu, zatímco substantivum preferuje $\mathrm{N}$-formu (viz frekvence $\mathrm{v}$ tabulce 1 ).

\begin{tabular}{|c|c|c|c|c|c|c|c|}
\hline \multicolumn{4}{|c|}{ Adjektiva } & \multicolumn{4}{|c|}{ Substantiva } \\
\hline \multirow[t]{2}{*}{$\begin{array}{l}\text { lemma + } \\
\text { předložka }\end{array}$} & \multicolumn{3}{|c|}{$\begin{array}{c}\text { počet dokladů } \\
\text { (absolutní frekvence) }\end{array}$} & \multirow[t]{2}{*}{$\begin{array}{l}\text { lemma }+ \\
\text { předložka }\end{array}$} & \multicolumn{3}{|c|}{$\begin{array}{c}\text { počet dokladů } \\
\text { (absolutní frekvence) }\end{array}$} \\
\hline & A-forma & $\mathrm{N}$-forma & $\begin{array}{c}\text { poměr } \\
\mathrm{N}: \mathrm{A} \\
(\mathrm{x} 100)\end{array}$ & & A-forma & $\mathrm{N}$-forma & $\begin{array}{c}\text { poměr } \\
\mathrm{N}: \mathrm{A} \\
(\mathrm{x} 100)\end{array}$ \\
\hline $\begin{array}{l}\text { informo- } \\
\text { vaný o+6 }\end{array}$ & 929 & 20 & 2,2 & $\begin{array}{l}\text { informo- } \\
\text { vanost } \\
\text { o+6 }\end{array}$ & 3496 & 131 & 3,7 \\
\hline jistý z & 244 & 78 & 32 & jistota $\mathrm{z}$ & 606 & 1269 & 209,4 \\
\hline $\begin{array}{l}\text { náročný } \\
\text { na+4 }\end{array}$ & 19206 & 2444 & 12,7 & $\begin{array}{l}\text { náročnost } \\
\text { na+4 }\end{array}$ & 1962 & 321 & 16,4 \\
\hline ochotný $\mathrm{k}$ & 2752 & 60 & 2,2 & ochota k & 4482 & 1048 & 23,4 \\
\hline $\begin{array}{l}\text { přátelský } \\
\mathrm{k}\end{array}$ & 2009 & 275 & 13,7 & $\begin{array}{l}\text { přátelství } \\
\mathrm{k}\end{array}$ & 589 & 588 & 99,8 \\
\hline $\begin{array}{l}\text { připrave- } \\
\text { ný na+4 }\end{array}$ & 19386 & 330 & 1,7 & $\begin{array}{l}\text { připrave- } \\
\text { nost na+4 }\end{array}$ & 2219 & 217 & 9,8 \\
\hline $\begin{array}{l}\text { spokoje- } \\
\text { ný s }\end{array}$ & 81348 & 6206 & 7,6 & $\begin{array}{l}\text { spokoje- } \\
\text { nost s }\end{array}$ & 12314 & 15786 & 128,2 \\
\hline $\begin{array}{l}\text { srovnatel- } \\
\text { ný s }\end{array}$ & 46114 & 2192 & 4,8 & $\begin{array}{l}\text { srovnatel- } \\
\text { nost s }\end{array}$ & 102 & 8 & 7,8 \\
\hline trpělivý s & 40 & 7 & 17,5 & $\begin{array}{l}\text { trpělivost } \\
\mathrm{s}\end{array}$ & 4132 & 67 & 1,6 \\
\hline $\begin{array}{l}\text { vděčný } \\
\mathrm{za}+4\end{array}$ & 10365 & 7 & 0,07 & $\begin{array}{l}\text { vděčnost } \\
\mathrm{za}+4\end{array}$ & 1210 & 7 & 0,6 \\
\hline věrný s & 79 & 516 & 653,2 & nevěra s & --- & 898 & --- \\
\hline $\begin{array}{l}\text { závislý } \\
\text { na+6 }\end{array}$ & 77814 & 10051 & 12,9 & $\begin{array}{l}\text { závislost } \\
\text { na+6 }\end{array}$ & 80877 & 6755 & 8,4 \\
\hline zkušený s & 120 & 11 & 9,2 & $\begin{array}{l}\text { zkušenost } \\
\mathrm{s}\end{array}$ & 122412 & 390 & 0,3 \\
\hline $\begin{array}{l}\text { zodpo- } \\
\text { vědný } \\
\text { za+4 }\end{array}$ & 33398 & 16 & 0,05 & $\begin{array}{l}\text { zodpo- } \\
\text { vědnost } \\
\text { za+4 }\end{array}$ & 19714 & 21 & 0,1 \\
\hline
\end{tabular}




\begin{tabular}{|c|c|c|c|c|c|c|c|}
\hline \multicolumn{4}{|c|}{ Adjektiva } & \multicolumn{4}{|c|}{ Substantiva } \\
\hline \multirow[t]{2}{*}{$\begin{array}{l}\text { lemma }+ \\
\text { předložka }\end{array}$} & \multicolumn{3}{|c|}{$\begin{array}{c}\text { počet dokladů } \\
\text { (absolutní frekvence) }\end{array}$} & \multirow[t]{2}{*}{$\begin{array}{l}\text { lemma }+ \\
\text { předložka }\end{array}$} & \multicolumn{3}{|c|}{$\begin{array}{c}\text { počet dokladi̊ } \\
\text { (absolutní frekvence) }\end{array}$} \\
\hline & A-forma & $\mathrm{N}$-forma & $\begin{array}{c}\text { poměr } \\
\mathrm{N}: \mathrm{A} \\
(\mathrm{x} 100)\end{array}$ & & A-forma & N-forma & $\begin{array}{c}\text { poměr } \\
\mathrm{N}: \mathrm{A} \\
(\mathrm{x} 100)\end{array}$ \\
\hline $\begin{array}{l}\text { způsobilý } \\
\mathrm{k}\end{array}$ & 2682 & 919 & 34,3 & $\begin{array}{l}\text { způsobi- } \\
\text { lost k }\end{array}$ & 5022 & 184 & 3,7 \\
\hline $\begin{array}{l}\text { zvědavý } \\
\text { na }+4\end{array}$ & 7788 & 0 & 0 & $\begin{array}{l}\text { zvědavost } \\
\text { na+4 }\end{array}$ & 289 & 1 & 0,3 \\
\hline $\begin{array}{l}\text { zvyklý } \\
\text { na+4 }\end{array}$ & 25197 & 177 & 0,7 & $\begin{array}{l}\text { zvyklost } \\
\text { na+4 }\end{array}$ & 76 & 4 & 5,3 \\
\hline
\end{tabular}

Tabulka 1. Srovnání počtu výskytů afirmativních a negovaných forem následovaných předložkou v SYNv8

$\mathrm{V}$ souvislosti s frekvencí námi zkoumaných A-forem a $\mathrm{N}$-forem adjektiv a deadjektivních substantiv následovaných předložkou lze vysledovat určité tendence v uplatnění jejich předložkové valence:

(i) Předložková valence A-formy a $\mathrm{N}$-formy daného adjektiva nebo substantiva je přesvědčivě stejná, což se projevuje také $\mathrm{v}$ jejich vysokých absolutních frekvencích a v poměru počtu $\mathrm{N}$-formy ku počtu A-formy v rozmezí 0,015-0,35 (v tabulce 1,5-35), např. (ne)závislý na něčem, (ne)závislost na něčem.

(ii) Předložková valence A-formy a $\mathrm{N}$-formy daného adjektiva nebo substantiva je sice stejná, nízký poměr počtu $\mathrm{N}$-formy ku počtu $\mathrm{A}$-formy však naznačuje, že se $\mathrm{v}$ př́ípadě $\mathrm{N}$-formy jedná o formu mluvč́mi výrazně méně preferovanou, až okazionální, např. nevděčný za něco, nezvědavost na něco (oddíl 4.2.1).

(iii) Vzácně se vyskytují př́ípady negovaných adjektiv nebo deadjektivních substantiv, jejichž valence se od valence jejich afirmativních forem alespon částečně liší. V našem vzorku se jedná o adjektiva (ne)věrnýa a (ne)jistý (odd. 4.2.2).

(iv) Okrajové jsou také př́ípady, kdy je sice předložková valence stejná jak u A-formy, tak u N-formy určitého substantiva, valence základového adjektiva je však odlišná, srov. např. valenci s bezpředložkovým dativem u adjektiva (ne)sympatický (komu) a předložkovou valenci substantiva (ne)sympatie ( $k$ někomu).

(v) V př́padě, že je A-forma s předložkou vysoce frekventovaná, zatímco $\mathrm{N}$-forma je s toutéž předložkou doložená jen vzácně, může se v případě A-formy jednat o součást sekundárních předložek nebo jiných ustálených spojení (např. $v$ souvislosti $s$, ve spojitosti s, v návaznosti na, v součinnosti s). 


\subsubsection{Méně doložené př́ípady předložkové valence u negovaných adjektiv a deadjektivních substantiv}

U řady negovaných forem adjektiv nebo deadjektivních substantiv je možnost užití stejné předložkové valence jako u afirmativní formy nejasná a je třeba ji ověřit v korpusových datech. Přijatelnost takových konstrukcí záleží na jazykovém povědomí jednotlivých mluvčích, podle naší intuice kolísá od konstrukcí přijatelných až po prípady okazionální, napr. níže doklady nenutný (16) a nezvědavost (27).

V př́kladech (15)-(21) uvádíme korpusové doklady ověřovaných předložkových valencí u vybraných $\mathrm{N}$-forem adjektiv, konkrétně neinformovaný $o$, nenutný k, netrpělivýs, nevděčný za, nezkušenýs, nezodpovědný za a nezvyklý na.

(15) Neinformovaní o současných podmínkách na trhu práce jsou totiž nejen vycházející školáci.

(16) Provedení důkazu výslechem navrhovaných bývalých př́itelkyň obžalovaného ... soud zamítl jako nenutné $\mathbf{k}$ objasnění věci.

(17) Byl už skutečně netrpělivý s jeho leností a pasivitou?

(18) Největší zlom přišel po roce 2010, kdy se část stř̌ední třídy, očividně nevděčná za stoupající ekonomický blahobyt, aktivizovala a začala otevřeně kritizovat korupci.

(19) Osobám absolutně nezkušeným s vyplňováním žádostí o podporu se může zdát celý proces náročný.

(20) Jako by mládí činilo člověka nezodpovědným za jeho jednání a morálně jej očištovalo.

(21) Člověku nezvyklému na alkohol by takové množství způsobilo těžkou otravu.

V př́kladech (22)-(28) dokládáme ověřované předložkové valence vybraných negovaných forem deadjektivních substantiv, konkrétně nesrovnatelnost $s$, netrpělivost $s$, nevděčnost za, nezkušenost $s$, nezodpovědnost za, nezvědavost na a nezvyklost na, přičemž k substantivu nezvyklost (28) uvádíme i málo frekventovanou afirmativní formu se stejnou valencí, tj. zvyklost na v (29).

(22) To, co Estonci chápou jako nutné kroky k „estonizaci Estonska“, Moskva velmi bolestně pocituje jako protiruské akce, ba jako nevděčnost za hospodářský rozvoj, do něhož se tolik investovalo.

(23) je si vědom i své absolutní nesrovnatelnosti se zakladatelem státu

(24) jiní dávají najevo svou netrpělivost $\mathbf{s}$ délkou oprav v Zenklově ulici

(25) mnoha lidem vadila i jeho nezkušenost s globálními problémy

(26) dávají tím však také najevo svoji nezodpovědnost za sebe samé, své rodiny a obce 
(27) České buranství ve smyslu vulgarity, šovinismu a celkové omezenosti a nezvědavosti na svět, to jsou věci, které špatně snáším.

(28) v podřepu jsem lákal tu kočku, chtěla, abych ji pohladil, ale opuštěnost a nezvyklost na lidskou vůni ji vždycky odstřelila

(29) medvěd na Vsetínsku, který kvůli své zvyklosti na lidi nepřirozeně obtěžoval obyvatelstvo a vybíjel jim ohrady

\subsubsection{Rozdíly ve valenci $\mathrm{N}$-forem a A-forem adjektiv a deadjektivních substantiv}

$\mathrm{V}$ našem vzorku negovaných forem adjektiv a deadjektivních substantiv jsme zaznamenali pouze dva př́pady, kdy se valence negované a afirmativní formy alespoň částečně liší. Jedná se o adjektiva (ne)věrný a (ne)jistý.

Adjektivum (ne)věrný i od něj odvozené deadjektivum (ne)věrnost má valenci s Patientem vyjádřeným bezpředložkovým dativem, užívanou obecně pro vyjádření zachování nebo porušení závazku vủči určitým zásadám, srov. (30), nejčastěji však pro vyjádření zachování nebo porušení věrnosti v partnerském vztahu, viz (31)-(32). V tomto běžnějším případě má však adjektivum nevěrný širší valenční potenciál než adjektivum věrný; zatímco valence adjektiva věrný je dostatečně naplněna Patientem, adjektivum nevěrný vyžaduje valenci s dalším aktantem, totiž s Adresátem, důležitým pro vyjádření tř̌etího účastníka dané situace, tj. s kým $\mathrm{k}$ porušení věrnosti došlo (33). Zcela ojedinělé užití adjektiva věrný s Adresátem v (34) je nejen prŕźznakové, ale je zřejmým prostředkem jazykové ironie. Substantivum (ne)věrnost se však s Adresátem vyjádřeným předložkovou skupinou $s+7$ nevyskytuje a místo něj je v těchto situacích užíváno substantivum nevěra, viz (35), které si zachovává i dativní valenci, viz (36).

(30) jejich.ACT nevěrnost předvolebním programům.PAT

(31) Většina mužů je monogamních, mnozí jsou nevěrní svým partnerkám.PAT

(32) Můj rabín říká, že nevěrnost muži.PAT je strašný hřích.

(33) Celá situace je zajímavá zápletkou: jeho žena je nevěrná svému milenci.PAT se svým vlastním manželem.ADDR.

(34) Pro př́tele - Drahý, nemáš důvod na mě žárlit. Celý pobyt jsem Ti.PAT věrná s Honzou.ADDR, Jirkou.ADDR, Petrem.ADDR, Tomášem.ADDR...

(35) Vydrželi spolu patnáct let, než jejich manželství rozbily jeho.ACT nevěry $s$ jinými kráskami.ADDR.

(36) zprávy o jeho.ACT nevěrách manželce.PAT Victorii

Jiná situace nastává u adjektiva (ne)jistý. Toto adjektivum má valenci s Patientem vyjádřeným různými morfematickými formami, např. bezpředložkovým 
instrumentálem v (37) a (38) nebo vedlejší větou v (39) ${ }^{10}$. Adjektivum nejistý se však na rozdíl od adjektiva jistý vyskytuje také s valenčním doplněním vyjádřeným předložkovou skupinou $z+\mathrm{Gen}$, viz (40); v těchto př́padech není zřejmé, zda se jedná o další aktant, konkrétně Původ, rozvíjející stejný význam adjektiva nejistý, nebo zda adjektivum nejistý získává nový sémantický příznak znejistělý, který by měl být ve slovníku zachycen jako zvláštní lexikální jednotka. Pohled na počty dokladů odvozeného substantiva (ne)jistota v tabulce 1 ukazuje, že doplnění $z+G e n$ je sice výrazně běžnější u $\mathrm{N}$-formy, viz (41), vyskytuje se však i u substantiva v A-formě, viz (42), aniž by byl zřejmý významový rozdíl oproti substantivu (ne)jistota rozvitému Patientem v bezpředložkovém genitivu v (43) a (44).

(37) může si být Alžběta jistá respektem.PAT a obdivem.PAT svých poddaných

(38) Na místě je i poradna pro houbaře nejisté si svým úlovkem.PAT.

(39) začal být lehce nejistý, zda něco nezanedbal.PAT při výchově potomstva

(40) Spotřebitelé se cítí velice nejistí $\mathbf{z}$ dalšího vývoje.

(41) Nejhorší je moje nejistota $\mathbf{z}$ budoucnosti.

(42) Jistota $\mathbf{z}$ vítězství pronikla do všech obydlí. (= jistota vítězství?)

(43) Ukazuje se, že naše.ACT jistota blahobytu.PAT a bezpečí.PAT může být falešná.

(44) je metaforou lidské existence v její.ACT nejistotě hledání.PAT smyslu bytí

\section{Diskuse}

V této práci jsme se zaměřili na adjektiva a abstraktní substantiva, která tvořínegované formy a mají stejný (pouze negovaný) význam jako jejich afirmativní formy. Na základě našeho jazykového materiálu (odd. 3) můžeme konstatovat, že pokud negované formy adjektiv nebo substantiv existují, mají v naprosté většině př́padů stejnou předložkovou valenci jako jejich afirmativní formy (odd. 4). Předložková valence je většinou stejná jak u adjektiva, tak u odvozeného substantiva, např.

${ }_{10}$ Rozvití adjektiva (ne)jistý vedlejší větou uvozenou spojkami $z$ da/jestli a že má určitá omezení. U adjektiva nejistý převažují vedlejší věty uvozené spojkami $z$ da/jestli, viz (39), nad větami uvozenými spojkou že, srov. zcela ojedinělý korpusový doklad Odběratelé si jsou nejistí, že zakázky stihneme dotáhnout do konce března. U adjektiva jistý je tomu naopak, tj. převažují doklady s vedlejší větou uvozenou spojkou že, např. je si jistý, že bude moc přijít, nad větami uvozenými spojkami $z d a / j e s t l i$; ty se běžně vyskytují v negovaných konstrukcích typu není si jistý, $z d a$ bude moct prìít, ale v kladných konstrukcích je jejich výskyt omezený, srov. je si jistý, ${ }^{\star} z d a$ bude moct príijit vs. aby si byl jistý, zda bude moct prijít (srov. korpusový doklad abychom si byli jisti, zda je možné zvýšit poplatky za služby). Podobné problematice, tj. souvislosti větné negace a souvýskytu adjektiv s vedlejšími větami podmětnými uvozenými určitými spojkami (např. je jisté, že/* $z d a$ se to stane vs. není jisté, že/zda se to stane), se na př́kladu norských adjektiv kjent 'známý', klar 'jasný' a sikker 'jistý' věnuje Haugen (2013, s. 45-47). 
(ne)spokojenýs ším / (ne)spokojenost s čím, okrajově se valence adjektiva a od něj odvozeného substantiva liší, srov. (ne)sympatický komu vs. (ne)sympatie ke komu. Př́pady odlišné předložkové valence afirmativních a negovaných forem českých adjektiv nebo deadjektivních substantiv jsou zcela ojedinělé (např. nevěrný s kým, nejistý $z$ čeho; odd. 4.2.2), rozdíly je však možné sledovat ve frekvenci afirmativních nebo negovaných forem se stejnou valencí (např. vysoce frekventované $z o d-$ povědný za něco, ale zcela okrajové nezodpovědný za něco; tabulka 1 a odd. 4.2.1).

Otázka zachycení afirmativních a negovaných forem adjektiv a substantiv v rámci jednoho hesla ve valenčním slovníku však nadále zůstává otevřená. Vedle předložkové valence by bylo třeba ověřit, zda negované a afirmativní formy mají stejnou valenci, i pokud jde o jiná morfematická vyjádření (ani zde však neočekáváme výrazné rozdíly, viz např. doklady adjektiv se stejnou bezpředložkovou valencí jak u A-formy, tak u $\mathrm{N}$-formy v odd. 4.2.2, konkrétně (ne)věrný komu a (ne)jistý čím, dále např. (ne)znalost čeho nebo (ne)schopnost udělat). Ukazuje se, že spíše než rozdíly ve valenci vyvolává otázky zachycení méně doložených prrípadů negovaných forem a jejich valence. $U$ vysoce frekventovaných adjektiv nebo substantiv s hojně doloženými valenčními doplněními by zachycování A-forem a $\mathrm{N}$-forem $\mathrm{v}$ oddělených heslech vedlo ke zbytečné redundanci ve slovníku; u nich by tedy bylo možné uvažovat o zachycení obou forem (A-formy i $\mathrm{N}$-formy) v rámci jednoho hesla. U méně frekventovaných adjektiv a substantiv by však bylo třeba posoudit každý jednotlivý př́pad zvlášt. Řešením by mohlo být primárně zachytit ve slovníku afirmativní formy adjektiv a substantiv, spolu s jejich valencí, a v př́padě, že jejich $\mathrm{N}$-forma existuje a její valence se přesvědčivě od A-formy neliší, poznamenat tuto skutečnost do zvláštního atributu (např. N-forma: ano / ne, frekvence: vysoká / průměrná / nízká) a př́slušné doklady uvést $\mathrm{v}$ př́íkladové části hesla. Negované formy s odlišným významem nebo s odlišnou valencí by měly být zachyceny ve zvláštním hesle (jak jsme však viděli např. u adjektiva nevěrný v odd. 4.2.2, význam adjektiva zůstává stejný, jen se mění počet účastníků situace, které jeho valenční struktura zachycuje).

Další otázkou je, zda v př́ípadě zachycení v rámci jednoho hesla zohledňovat, zda dané adjektivum nebo substantivum preferuje afirmativní, nebo negovanou formu. $\mathrm{Z}$ našeho vzorku je zřejmé, že př́pady adjektiv a substantiv preferujících afirmativní formu výrazně převažují, existují ale i př́ípady opačné, kdy je preferovaným tvarem $\mathrm{N}$-forma (např. nepostradatelný, nezbytný, nezaměstnanost), přestože $\mathrm{k}$ němu afirmativní forma existuje. Je tedy otázka, zda by mělo být zvoleno jednotné řešení, např̀. v hesláři vždy uvádět afirmativní formu (jako je tomu např. v PDT-Vallexu, přičemž výsledkem takto důsledného řešení je pak např. heslo zbytný), nebo zda u každého adjektiva a substantiva rozhodnout $\mathrm{o}$ jejich formě $\mathrm{v}$ hesláři individuálně, na základě frekvence jejich $\mathrm{A}$-forem, resp. $\mathrm{N}$-forem. 
U deverbativních substantiv by bylo možné uvažovat o plošném zpracování $\mathrm{v}$ rámci jednoho hesla pouze $\mathrm{v}$ př́padě $\mathrm{A}$-forem a $\mathrm{N}$-forem kmenových derivátů označujících událost (např. (ne)odpovězení na něco, (ne)zajímání se o něco). U dalších abstraktních významů kmenových derivátů (např. (ne)nadšení z čeho) a u kořenových derivátů (např. (ne)obliba $v$ čem) by však bylo opět třeba navrhnout takové slovníkové zpracování, které bude schopné co nejjednotnějším způsobem postihnout jejich individuální vlastnosti.

\section{Závěr}

Naše analýza valenčního chování afirmativních a negovaných forem českých adjektiv a deverbativních a deadjektivních substantiv ukázala, že jejich předložková valence se až na výjimky shoduje. Otázku, zda je tedy možné jejich valenci ve valenčním slovníku zachytit v rámci jednoho hesla, však necháváme zatím otevřenou. Kromě prozkoumání dalších morfematických vyjádření valenčních doplnění negovaných forem zbývá navrhnout takové slovníkové zpracování, které by bylo schopné jednotným způsobem zachytit individuální vlastnosti jednotlivých adjektiv a substantiv, tedy např. rozdíly v preferenci afirmativní nebo negované formy a také rozdíly v potencialitě vyjádření valenčních doplnění negovaných forem, zohledňující nejen vysoce frekventované, ale i méně doložené př́pady.

\section{Bibliografie}

Caha, P. (2016). Pasivní participium. In: P. Karlík et al. (eds.), Nový encyklopedický slovník češtiny (1299-1302). Praha: Nakladatelství Lidové noviny.

Curiel, M.M. (2015). Negation. In: P.O. Müler et al., Word-Formation. An International Handbook of the Languages of Europe. Volume 2 (1351-1359). Berlin-Boston: De Gryuter Mouton.

Čermáková, A. (2009). Valence českých substantiv. Praha: Nakladatelství Lidové noviny.

Dvořák, V. (2016a). Dějové substantivum. In: P. Karlík et al. (eds.), Nový encyklopedický slovník češtiny (309-315). Praha: Nakladatelství Lidové noviny.

Dvořák, V. (2016b). Verbální substantivum. In: P. Karlík et al. (eds.), Nový encyklopedický slovník češtiny (1948-1953). Praha: Nakladatelství Lidové noviny.

Hajič, J. et al. (2003). PDT-VALLEX: Creating a Largecoverage Valency Lexicon for Treebank Annotation. In: Proceedings of The Second Workshop on Treebanks and Linguistic Theories (57-68). Vaxjo University Press.

Haugen, T.A. (2013). Adjectival valency as valency constructions. Evidence from Norwegian, Constructions and Frames, 5, 1, 35-68. 
Jimenez-Zafra, S.M. et al. (2020). Corpora Annotated with Negation: An Overview, Computational Linguistics, 46, 1, 189-244.

Karlík, P. (2019). Škála nominalizací. In: P. Malčík, P. Karlík (eds.), Svět podle Grepla (91-110). Brno: Host.

Karlík, P., Ziková, M. (2016). -teln-adjektivum. In: P. Karlík et al., Nový encyklopedický slovník češtiny (1826-1829). Praha: Nakladatelství Lidové noviny.

Kolářová, V. et al. (2020). Nom Vallex I. Valenční slovník substantiv. Praha: Ústav formální a aplikované lingvistiky.

Kopřivová, M. (2006). Valence českých adjektiv. Praha: Nakladatelství Lidové noviny.

Kováŕíková, D. (2011). Gramatická kategorie negace. In: F. Čermák (ed.), Korpusová lingvistika Praha 2011. 2: Výzkum a výstavba korpusů (273-280). Praha: Nakladatelství Lidové noviny.

Kováríková, D. et al. (2012). What Belongs in a Dictionary? The Example of Negation in Czech. In: R.V. Fjeld, J.M. Torjusen (eds.), Proceedings of the 15th EURALEX International Congress (822-827). Oslo: Department of Linguistics and Scandinavian Studies, University of Oslo.

Křen, M. et al. (2019). Korpus SYN, verze 8 z 12.12.2019. Ústav Českého národního korpusu FF UK. http://www.korpus.cz/.

Mikulová, M. et al. (2005). Anotace na tektogramatické rovině Pražského závislostního korpusu. Anotátorská príručka. Praha: ÚFAL MFF UK.

Osolsobě, K. (2014). Česká morfologie a korpusy. Praha: Karolinum.

Panevová, J. (1980). Formy a funkce ve stavbě české věty. Praha: Academia.

Panevová, J. (1998). Ještě k teorii valence, Slovo a slovesnost, 59, 1-14.

Panevová, J. (2002). K valenci substantiv (s ohledem na jejich derivaci), Zbornik Matice srpske za slavistiku, 29-36.

Panevová, J. (2006). Na co jsme pyšní a čemu zůstaneme věrní (poznámky k valenci několika českých adjektiv). In: F. Štícha (ed.), Možnosti a meze české gramatiky (153-166). Praha: Academia.

Pavlovič, J. (2015). Negation in the Slavic and Germanic languages. In: P.O. Müler et al., Word-Formation. An International Handbook of the Languages of Europe. Volume 2 (1360-1373). Berlin-Boston: De Gryuter Mouton.

Prouzová, H. (1983). K valenčním vlastnostem primárních adjektiv v češtině, Slovo a slovesnost, 44, 265-274.

Rechzieglová, A. (1995). On Negation in Czech. Praha: Euroslavica.

Richterová, O. (2017). Od slovesa ke jménu a předložkám. Departicipiální formy v češtinè: forma, funkce, konkurence. Disertační práce. Praha: Univerzita Karlova.

Rusínová, Z. (2016). Modifikace. In: P. Karlík et al. (eds.), Nový encyklopedický slovník češtiny (1064). Praha: Nakladatelství Lidové noviny. 
Rusínová, Z., Osolsobě, K. (2016). Prefixace. In: P. Karlík et al. (eds.), Nový encyklopedický slovník češtiny (1394-1395). Praha: Nakladatelství Lidové noviny.

Skwarska, K. (2018). Valence adjektiv v komparativním pohledu (na materiálu češtiny, ruštiny a polštiny), Slavia, $87,1-3,302-315$.

Sokolová, M. et al. (1999). Morfematický slovník slovenčiny. Prešov: Náuka.

Svozilová, N. et al. (2005). Slovník slovesných, substantivních a adjektivních vazeb a spojení. Praha: Academia.

Ševčíková, M. et al. (2016). Lexikální sít DeriNet: elektronický zdroj pro výzkum derivace v češtině, Časopis pro moderní filologii, 98, 1, 62-76.

Šimandl, J. et al. (2016). Slovník afixů uživaných v češtině. Praha: Karolinum.

Štícha, F. et al. (2013). Akademická gramatika spisovné češtiny. Praha: Academia.

Veselá, K. (2004). Negace u adjektiv, substantiv a adverbií. Nepublikovaný interní materiál ÚFAL MFF UK.

ABSTRAKT: Při zpracování valence adjektiv a substantiv ve valenčním slovníku je třeba rozhodnout, zda je možné jejich afirmativní a negované formy zpracovat $\mathrm{v}$ jednom hesle, např. (ne)závislý, (ne)závislost. Kromě rozdílů ve významu afirmativní a negované formy, např. volnost (svoboda) vs. nevolnost (nepř́iemný tělesný stav), by k vydělení zvláštního hesla vedla také jejich odlišná valence (srov. anglické dependent on vs. independent of). Naše korpusová analýza ukazuje, že negované formy českých adjektiv a substantiv mají až na výjimky stejnou předložkovou valenci jako jejich afirmativní formy (např. (ne)spokojený s čím, (ne)spokojenost s čím), liší se však jejich frekvence. Při zpracování afirmativních a negovaných forem $v$ jednom hesle je vedle běžných př́padů třeba jednotným způsobem ošetřit jak méně doložené negované formy a jejich valenci (např. nevděčný za něco), tak prrípady, kdy frekvence negované formy a její valence naopak převažuje nad afirmativní formou (nepostradatelný pro nékoho).

\title{
RELACJA AFIRMATYWNYCH I NEGATYWNYCH FORM PRZYMIOTNIKÓW I RZECZOWNIKÓW Z PUNKTU WIDZENIA ICH WALENCJI
}

\begin{abstract}
ABSTRAKT: Przy opracowaniu walencji przymiotników i rzeczowników w słowniku walencyjnym należy zdecydować, czy możliwe jest opracowanie w jednym haśle ich form twierdzących i zanegowanych, np. (ne)závislý, (ne)závislost. Oprócz różnic w znaczeniu form twierdzących i zanegowanych, takich jak volnost ('wolność') vs. nevolnost ('nudności'), ich różna walencja prowadziłaby również do opracowania specjalnego hasła (por. ang. dependent on $\mathrm{x}$ independent of). Nasza analiza korpusowa pokazuje, że zanegowane formy czeskich przymiotników i rzeczowników mają, z pewnymi wyjątkami,
\end{abstract}


identyczną walencję przyimkową, jak ich formy twierdzące (np. (ne)spokojený s čím, (ne) spokojenost s čím), ale ich częstotliwość jest różna. Przy przetwarzaniu form twierdzących i zanegowanych w jednym haśle, oprócz zwykłych przypadków, należy traktować w jednolity sposób zarówno mniej udokumentowane formy zanegowane i ich walencję (np. nevděčný za něco), jak i przypadki, w których frekwencja i walencja formy zanegowanej przeważa nad formą afirmatywną (nepostradatelný pro někoho). 